\title{
A new genus Mesophlaeoba (Orthoptera: Acrididae: Acridinae) from India
}

\author{
H. Kumar, M.K. Usmani \\ Section of Entomology, Department of Zoology, Aligarh Muslim University, India
}

\begin{abstract}
A new genus of Acridinae, Mesophlaeoba Kumar and Usmani gen. $n$. based on type species Mesophlaeoba usmanii Kumar and Usmani sp. n., is described and illustrated from India. The description was based on both conventional morphological and genital characters. The new genus is closely related to Phlaeoba Stal, 1861 but differs from it in presence of filiform antennae, absence of median carinula of fastigium of vertex and rounded posterior margin of pronotum.
\end{abstract}

Correspondence: Hirdesh Kumar, Section of Entomology, Department of Zoology, Aligarh Muslim University, Aligarh 202002, Uttar Pradesh, India. Tel.: +91.0571.2700920.

E-mail: entomologist1985@gmail.com

Key words: Mesophlaeoba; Acridinae; new genus; new species; India.

Contributions: HK has collected and identified the material under study, description, photography, illustration and manuscript were prepared for new taxa; MKU has critically gone through the manuscript and made necessary corrections/modifications and also confirm the identification.

Conflict of interest: the authors declare no potential conflict of interest.

Acknowledgments: we wish to extend our gratitude to Department of Science and Technology, New Delhi for providing financial assistance during the tenure of a major research project (Ref. No. SR/SO/AS 32/2008) being carried out on Biosystematics and Biodiversity of Acridoidea (Orthoptera) in North India. Thanks are also due to Prof. Iqbal Parwez, Chairman, Department of Zoology, Aligarh Muslim University for providing facilities.

To meet the requirements by the International Code of Zoological Nomenclature (ICZN), this article was registered at ZooBank (20 March 2015) under the ZooBank Life Science Identifier (LSID): 941EBBFE-61A24A87-82BD-3414B0D53671.

Received for publication: 17 February 2015.

Revision received: 14 March 2015.

Accepted for publication: 20 March 2015.

Published: 15 April 2015.

This work is licensed under a Creative Commons Attribution NonCommercial 3.0 License (CC BY-NC 3.0).

(c) Copyright H. Kumar and M.K. Usmani, 2015

Licensee PAGEPress, Italy

Entomologia 2015; 3:269

doi:10.4081/entomologia.2015.269

\section{Introduction}

Krauss (1890) was the first who used the family name Acrididae, but priority for family-group names based on Acrida dates from Acridina MacLeay, 1821 (Eades et al., 2014). Acrididae is divided into 25 subfamilies (Eades et al., 2014). However tribe Eucopiocerini with four genera and 12 other genera are remaining free from all subfamilies of Acrididae (Eades et al., 2014). The subfamily Acridinae is divided into 5 tribes, but within the subfamily 106 genera are not assigned to any tribe (Eades et al., 2014). Acridinae is represented by 138 genera worldwide (Eades et al., 2014); while in India, 36 species belonging to 15 genera were reported under Acridinae (Shishodia et al., 2010). The characteristic features of Acridinae are: absence of prosternal process, apical and basal valves of aedeagus flexured, bridge-shaped epiphallus; ancorae and lophi mostly present (Dirsh, 1961); posterior margin of female subgenital plate entirely setose, spermatheca with apical divertidulum short or rudimentary, preapical diverticulum saclike (Usmani \& Kumar, 2011). The present paper deals with the description and illustration of a new genus Mesophlaeoba Kumar and Usmani gen. n. and a new species Mesophlaeoba usmanii Kumar and Usmani sp. n. from India. The terminology used for external morphology is similar to that of Uvarov (1966) and for describing the female genitalia was used that of Slifer (1939) and Agarwala (1952). Holotype and paratypes of a new species are deposited in the Zoology museum, Aligarh Muslim University, India.

\section{Materials and Methods}

The authors collected new materials from grassland areas of Mandi and Solan districts of Himachal Pradesh, India. Dry mounts were prepared for morphological characters like size, color, texture etc. Images of Figure 1 were obtained using an Olympus SLR digital camera (Olympus, Center Valley, PA, USA) and camera mounted to a Nikon stereozoom microscope (Nikon Inc., Tokyo, Japan).

For a detailed study of the various components of genitalia, the permanent slides were prepared and examined under the microscope in order to make a detailed study of its structures. Drawings were initially made with the help of a camera lucida. Details were filled in by conventional microscope examination.

\section{Results: taxonomic account}

Genus: Mesophlaeoba Kumar and Usmani gen. n.

Type species: Mesophlaeoba usmanii Kumar and Usmani sp. n.

Description: Small to medium sized (Figure 1A); cylindrical, antennae 


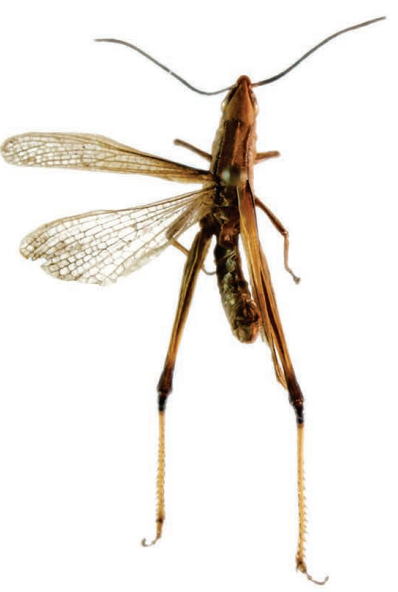

A

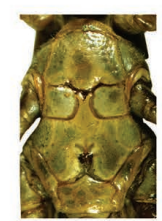

H

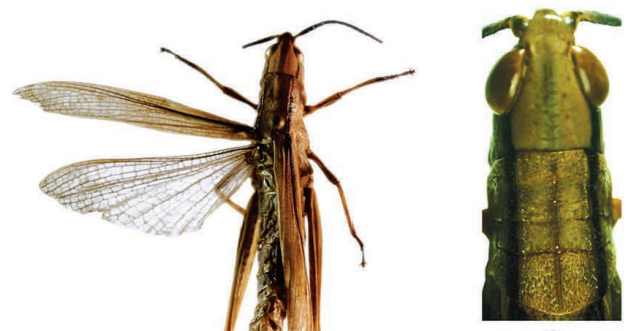

C

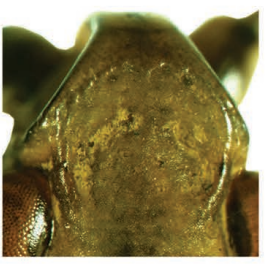

F

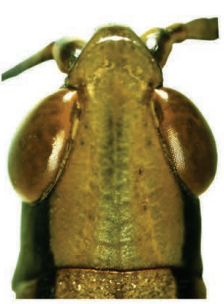

D

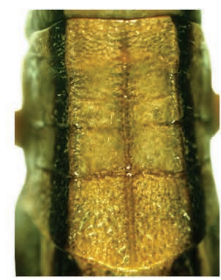

G
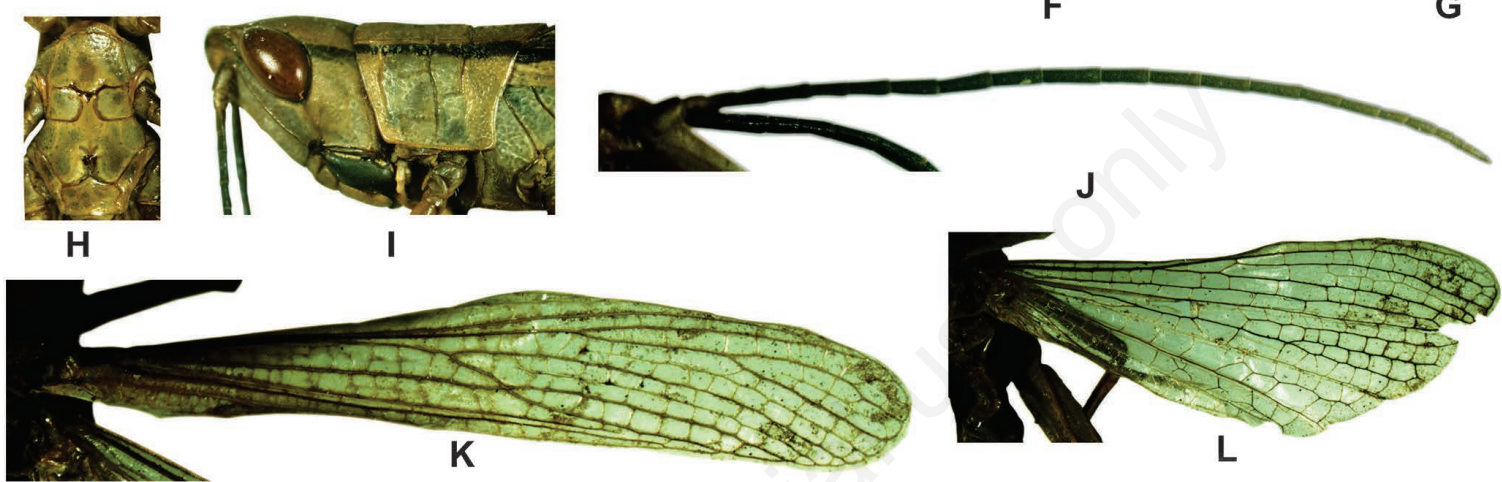

L
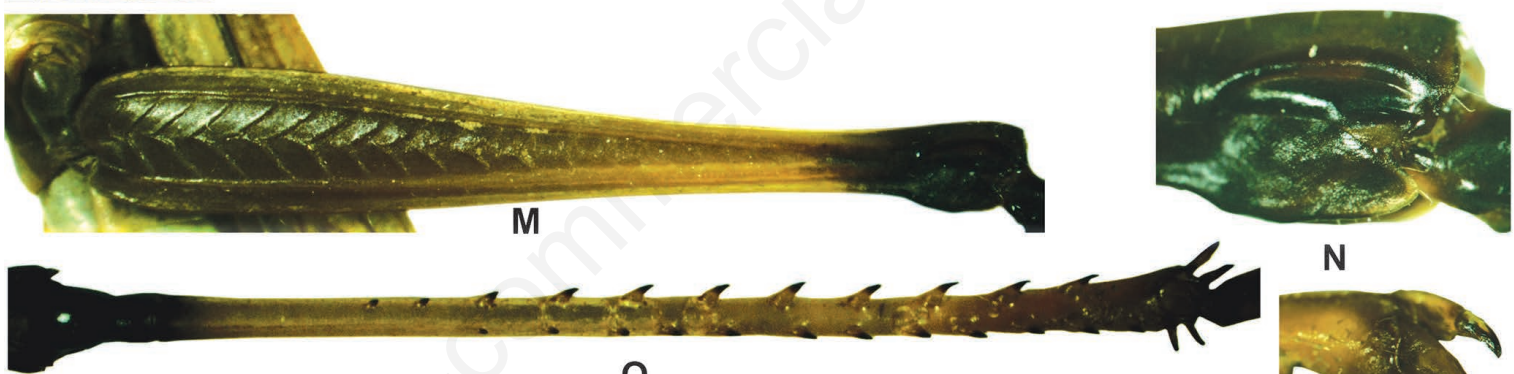

O

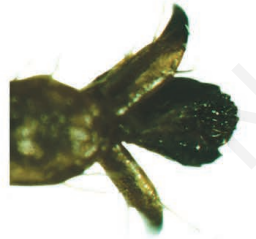

Q

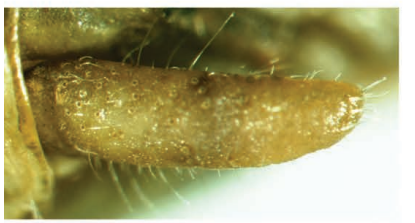

U

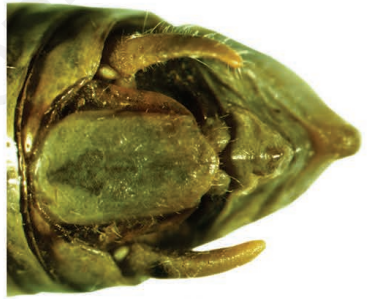

R

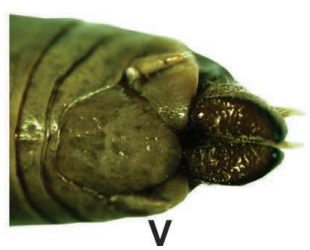

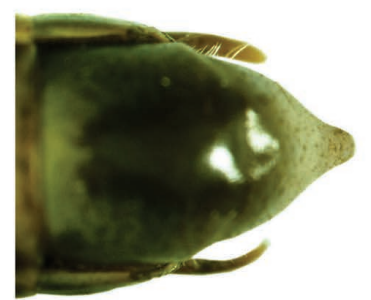

S

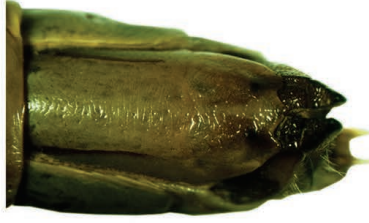

W
N

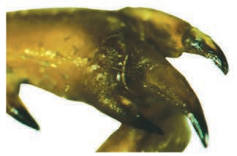

P

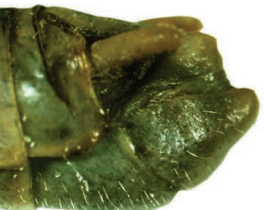

T

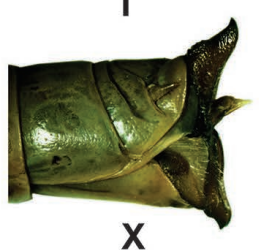

Figure 1. Mesophlaeoba usmanii Kumar and Usmani sp. n. (A-X). A) Dorsal view ${ }^{\text {; }}$; B) dorsal view $\odot$; C) dorsal view of head and pronotum ${ }^{3}$; D) dorsal view of head ${ }^{\text {; }}$ E) ventral view of head ${ }^{3}$; F) dorsal view of fastigium of vertex ${ }^{\circ}$;G) dorsal view of pronotum

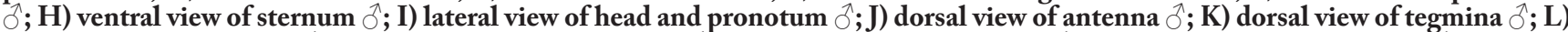
dorsal view of hind wing $\delta^{\lambda}$; M) dorsal view of hind femur ${ }^{\lambda}$; N) dorsal view of knee lobe ${ }^{\lambda}$; O) dorsal view of hind tibiae ${ }^{\lambda}$; P) dorsal

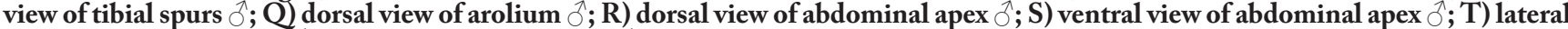

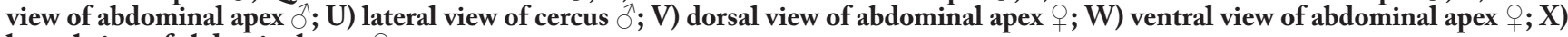
lateral view of abdominal apex $\odot$. 
(Figure 1J) filliform slightly flattened basally, longer than head and pronotum together (Figure 1C); head conical; fastigium of vertex (Figure 1F) angular, shorter than the longest diameter of eye without median carinula; fastigial foveolae absent; frons (Figure 1I) oblique; frontal ridge (Figure 1E) deeply sulcated; pronotum (Figure 1G) flat or slightly tectiform, smooth, median carina well developed, crossed by posterior transverse sulcus only, lateral carina straight, nearly parallel; metazona shorter than prozona, posterior margin rounded; prosternal process absent; mesosternal interspace (Figure 1H) open; tegmina (Figure $1 \mathrm{~K}$ ) and wings fully developed; hind femur (Figure 1M) thickened, inner side without stridulatory file; arolium (Figure 10) of medium size.

Male genitalia: Supra-anal plate (Figures 1R and 2A) elongate-angular, cercus (Figures $1 \mathrm{U}$ and 2A) narrow-conical, slightly incurved with obtuse apex; subgenital plate (Figure $1 \mathrm{~S}$ and 2B) short with obtusely rounded apex; epiphallus (Figure 2C), bridge narrow and undivided, ancorae large, lophi lobiform; aedeagus (Figure 2D) apical valve narrower and shorter than basal valve with upcurved and obtuse apex.

Female genitalia: Supra-anal plate (Figures 1V and 2E) broadly angular, cercus conical with obtuse apex; subgenital plate (Figures $1 \mathrm{~W}$ and 2F) broad, triangular with media process slightly longer than lateral lobes, posterior margin entirely setose; spermatheca (Figure 2G), apical divertidulum short, preapical diverticulum sac-like; ovipositor (Figures $1 \mathrm{X}$ and $2 \mathrm{H}$ ), dorsal valve much shorter than lateral apodeme.

\section{Discussion}

Both genera Acrida Linnaeus, 1758 and Truxalis Fabricius, 1775 differ from the new genus in the presence of elongated head and very long and slender hind femur. The new genus differs from Zygophlaeoba Bolivar, 1902, Phlaeobida Boliar, 1902, Paraphlaeoba Bolivar, 1902, Parodontomelus Ramme, 1929, Odontomelus Bolivar, 1890 and Carliola Uvarov, 1939 in the presence of fully developed tegmina which is short or rudimentary in all the above genera. Pasiphimus Bolivar, 1914 differs from new genus by the presence of longitudinal ridges on head and pronotum together. The genera viz. Sikkimiana Uvarov, 1940, Gymnobothrus Bolivar, 1889, Julea Bolivar, 1914 and Duroniopsis Bolivar, 1914 are different from new genus by the presence of curved lateral carinae of pronotum in prozona. Lateral carina of pronotum diverging in metazona in genera viz. Phlaeobacris Willemse 1932, Holopercna Karsch, 1891 and Orthochtha Karsch, 1891 which make them different from new genus. Pyrgophlaeoba Miller, 1929 and Bababuddinia Bolivar, 1918 differing from new genus by the irregular lateral carinae of pronotum. Neophlaeoba Usmani \& Shafee, 1983 differing from new genus by presence of fastigial foveolae.

The genus Mesophlaeoba is closely related to Phlaeoba Stal, 1861 in serrated upper carina of hind femur, parallel lateral carinae of pronotum in its whole length and antennae as long as or longer than head and pronotum together but differs from it for: i) the presence of almost filiform antennae which are slightly compressed basally but in Phlaeoba Stal, 1861 basal 1/3 segments of antennae are completely ensiform; ii) absence of median carinula of fastigium of vertex which is very prominent in Phlaeoba Stal, 1861 and clearly visible from tip to end of head dorsally; iii) presence of rounded depression in fastigium of vertex which is absent in Phlaeoba Stal, 1861; iv) rounded posterior margin of pronotum which is not completely rounded but slightly wavy in species of Phlaeoba Stal, 1861; v) epiphallus with short ancorae in Phlaeoba Stal, 1861 while they are comparatively large in new genus; vi) apical diverticulum of spermatheca is rudimentary in Phlaeoba Stal, 1861 while it is in short condition in new genus; vii) dorsal valve of ovipositor shorter than lateral apodeme in Phlaeoba Stal, 1861 while it is comparatively much shorter in new genus.

Due to the absence of prosternal process, flexure valves of aedeagus, bridge-shaped epiphallus, presence of ancorae and lophi, entirely setose posterior margin of female subgenital plate and spermatheca with apical divertidulum short, preapical diverticulum sac-like, Mesophlaeoba Kumar and Usmani gen. $n$. is arranged under the subfamily Acridinae.

Etymology: The name of the new genus Mesophlaeoba is given because it is close to the genus Phlaeoba Stal, 1861 and it is based on a new species.

\section{Description of Mesophlaeoba usmanii Kumar and Usmani sp. $n$.}

\section{Male}

Small to medium size (Figure 1A); body cylindrical; antennae (Figure 1J) slightly flattened basally, 22 segmented, longer than head and pronotum together (Figure 1C); head (Figure 1D) conical, shorter than pronotum; eyes oval in shape, near the apex, maximum diameter of eye slightly longer than the interocular distance; frons (Figure 1I) oblique; fastigium of vertex (Figure 1F) angular, wider than long and slightly produced in front of eyes, shorter than eye length, sulcated with lateral carinulae, without median carinula, apex obtusely rounded; vertex with fine median carina, width of vertex between the eyes wider than the frontal ridge between the antennal sockets; fastigial foveolae absent; frontal ridge (Figure 1E) very narrow and deeply sulcated with high lateral carina reaching up to the clypeus, margins diverging below median ocellus; pronotum (Figure 1G) flat or slightly tectiform, longer than its width, almost smooth with well developed media and lateral carinae, all the three transverse sulcus seen on dorsum of pronotum but only posterior one cross median carina, lateral carina parallel in its whole length, crossed by all the three transverse sulci, prozona longer than metazona, posterovantral angle (Figure 1I) rounded, posterior margin of pronotum rounded; prosternal process absent; mesosternal lobes (Figure $1 \mathrm{H}$ ) rounded and mesosternal interspace longer than wide, margins rounded; tegmina (Figure $1 \mathrm{~K}$ ) fully developed with rounded apex; hind wing (Figure 1L) slightly shorter than the tegmina; hind femora (Figure 1M) short and compressed laterally, upper carina weakly serrated while lower carina smooth, surpassing the tip of abdomen, upper apical lobe longer than lower (Figure 1N), inner margin of inner side without a row of stridulatory pegs; hind tibiae (Figure 10) cylindrical, shorter than hind femur with 14 outer and 12 inner spines, inner spur on inner side of hind tibia slightly longer than external one (Figure 1Q); arolium large.

Genitalia: Supra-anal plate (Figures 1R and 2A) elongate-angular, slightly longer than wide, lateral margins curved, apex obtusely rounded; cercus (Figures 1T,U and 2A) narrow-conical, shorter than supraanal plate, slightly less than three times as long as wide, slightly incurved with obtuse apex. Subgenital plate (Figures 1S and 2B) short, broadly angular, wider than long, apex obtusely rounded. Epiphallus (Figure 2C), bridge narrow and undivided, ancorae large, acute and incurved; lophi large and lobiform. Aedeagus (Figure 2D) flexured, apical valve narrow and upcurved, apex obtuse, narrower and shorter than basal valve, connected with basal valve with flexure; basal valve much broad with obtuse apex; gonopore process broad with acute apex.

\section{Female}

Same as male (Figure 1B), but larger in size.

Genitalia: Supra-anal plate (Figures $1 \mathrm{~V}$ and 2E) broadly angular, wider than long with rounded apex; cercus conical, shorter than supra-anal plate, less than two times as long as wide, with obtuse apex. Subgenital plate (Figures $1 \mathrm{~W}$ and $2 \mathrm{~F}$ ) broad, triangular with median process slightly longer than lateral lobes, posterior margin entirely setose; egg-guide 

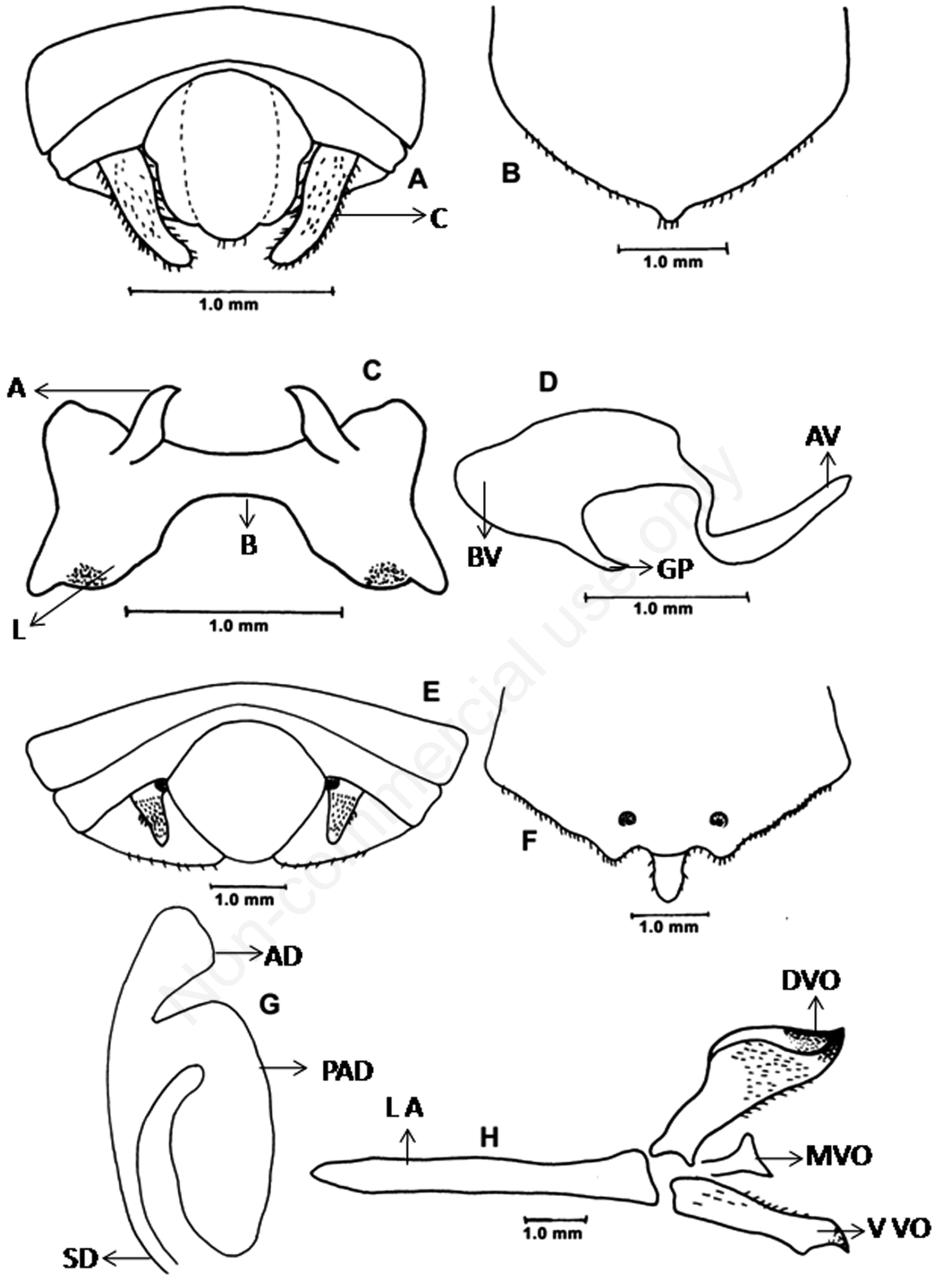

$1.0 \mathrm{~mm}$

Figure 2. Mesophlaeoba usmanii Kumar and Usmani sp. n. (A-H). A) Supra anal plate $\hat{\delta}$; B) subgenital plate $\delta^{\lambda}$; C) epiphallus $\delta^{\lambda}$; D) aedeagus ${ }^{\lambda}$; E) supra anal plate $\odot$; F) subgenital plate $\odot$; G) spermatheca + ; H) ovipositor $\odot$.

Abbreviations: A, ancorae; B, bridge; $C$, cercus; L, lophus; BV, basal valve; AV, apical valve; GP, gonopore process; $A D$, apical diverticulum; PAD, pre-apical diverticulum; SD, spermathecal duct; LA, lateral apodeme; DVO, dorsal valve of ovipositor, MVO, mesial valve of ovipositor; $\mathrm{VVO}$, ventral valve of ovipositor. 
short and broad, less than twice as long as wide, with rounded apex. Spermatheca (Figure 2G), apical diverticulum short with bulging and truncated apex, narrower and shorter than pre-apical diverticulum; preapical diverticulum long, broad, sac like. Ovipositor (Figures 1X and 2H), dorsal valve much broader and curved, much shorter than lateral apodeme, more than two times longer than wide, apical tip small, curved and acute; ventral valve broad, curved with apical tip small, curved and acute; mesial valve dilated apically with obtuse apex.

\section{Type material}

Holotype: $\delta$, India, Himachal Pradesh, Mandi, 26-X-2010, on grasses (Hirdesh Kumar).

Paratypes: $2 \hat{\partial} \hat{\partial}, 1+$, (same data as holotype); Solan, $17 \hat{\jmath} \hat{\partial}, 3$ 우 , 03-XI-2010, on grasses.

\section{Measurements (length in $\mathrm{mm}$ )}

Male: Body: 23.45; Pronotum: 4.40; Antenna: 13.61; Tegmina: 16.46; Hind Femur: 14.77.

Female: Body: 41.10; Pronotum: 6.71; Antenna: 9.29; Tegmina: 26.25; Hind Femur: 21.17.

\section{Distribution}

Himachal Pradesh, India.

\section{Etymology}

Patronymic name is given in honor of Prof. M. K. Usmani who contributed significantly in the taxonomy of this group.

\section{References}

AGARWALA S.B.D., 1952 - A comparative study of the ovipositor in the Acrididae - I. - Indian J. Entomol. 14: 61-75.

BOLIVAR I. 1889 - Ortopteros de Africa del Museo de Lisboa. - J. Sci. Math. Phys. Nat. (Ser. 2). 1: 73-112.

BOLIVAR I., 1890 - Diagnosis de ortopteros nuevos. - Anales Soc. Esp. Hist. Nat. 19: 299-333.

BOLIVAR I., 1902 - Les Orthopteres de St. Joseph's College, a Trichinopoly (Sud de l'Inde). 3me partie. - Ann. Soc. Entomol. Fr. 70: 580-635.

BOLIVAR I., 1914 - Estudios entomologicos. Segunda parte. I. El grupo de los Euprepocnemes. II. Los Truxalinos del antiguo mundo. - Trab. Mus. Nac. Ci. Nat. (Ser. Zool.) 20: 110.

BOLIVAR I., 1918 - Contribucion al conocimiento de la fauna Indica. Orthoptera (Locustidae vel Acridiidae). - Rev. Ac. Madrid 16: 278$289,374-412$.

DIRSH V.M., 1961 - A preliminary revision of the families and subfam- ilies of Acridoidea (Orthopera, Insecta). - Bull. Br. Mus. Nat. Hist. (Entomol.) 10: 351-419.

EADES D.C., OTTE D., CIGLIANO M.M., BRAUN H., 2014 - Orthoptera Species File. Version 5.0/5.0. Available from: http://Orthoptera. SpeciesFile.org.

FABRICIUS J.C., 1775 - Systema entomologiae, sistens insectorum classes, ordines, genera, species, adiectis synonymis, locis, descriptionibus, observationibus. Kortii, Flensburg and Leipzig.

KARSCH F., 1891 - Verzeichnis der von Herrn Dr. Paul Preuss in Kamerun erbeuteten Acridiodeen. - Berl. Entomol. Zeitschr. 36: 175-196.

KRAUSS H.A., 1890 - Erklarung der Orthopteren-Tafeln, J. C. Savigny's in der "Description de I'Egypte". - Verh. Zool. Bot. Ges. Wien. 40: 227-272.

LINNAEUS C., 1758 - Systema Naturae, 10 $0^{\text {th }}$ ed. Vol 1. pp 424-433.

MACLEAY W.S., 1821 - Horae Entomologicae 2. - S. Bagster, London.

MILLER N.C.E., 1929 - A new genus of Malayan grasshoppers (Orthoptera: Acridiidae). - J. Fed. Malay States Mus. 14: 461-463.

RAMME W., 1929 - Afrikanische Acrididae. Revisionen und Beschreibungen wenig bekannter und neuer Gattungen und Arten. - Mitt. Zool. Mus. Berlin 15: 247-492.

SHISHODIA M.S., CHANDRA K., GUPTA S.K., 2010 - An annotated checklist of Orthoptera (Insecta) from India. - Rec. Zool. Surv. India 314: 1-366.

SLIFER E.H., 1939 - The internal genetalia of female Acridinae, Oedipodinae and Pauliniinae (Orthoptera, Acrididae). - J. Morphol. 65: 437-470.

STAL C., 1861 - Orthoptera species novas descripsit. - In: Kongliga Svenska Fregatten Eugenies Resa omkring jorden under befäl af C.A. Virgin, Aren 1851-1853. Vetenskapliga Iakttagelser pa H.M. Konung Oscar den Förstes befallning utgifna af K. Svenska Vetenskaps Akademien. Vol. II, Zoologi I. Insecta. Nordstedt and Söner, Stockholm, pp 299-350.

USMANI M.K., SHAFEE S.A., 1983 - A new genus and two species of the subfamily Acridinae (Orthopt. Acrididae) from India. - Mitt. Schweizer. Entom. Gesell. 56: 401-403.

USMANI M.K., KUMAR H., 2011 - Female genitalia as a taxonomic tool in the classification of Indian Acridoidea (Orthoptera). - J. Threat. Taxa 3: 2207-2210.

UVAROV B.P., 1939 - Twenty-four new generic names in Orthoptera. Ann. Mag. Nat. Hist. 11: 457-459.

UVAROV B.P., 1940 - Eleven new generic names in Orthoptera. - Ann. Mag. Nat. Hist. 11: 377-380.

UVAROV B.P., 1966 - Grasshoppers and locusts. A Handbook of general acridology. Anti-Locust Research Centre at the University Press, Cambridge.

WILLEMSE, C., 1932 - Description of some new Acrididae (Orthoptera) chiefly from China from the Naturhistoriska Riksmuseum of Stockholm.- Natuurhistorisch Maandblad 21: 104-107. 